\title{
EHMTI-0027. The neuropathic pain in vascular dementia
}

\author{
D Tertan ${ }^{1 *}$, OB Tertan ${ }^{2}$ \\ From 4th European Headache and Migraine Trust International Congress: EHMTIC 2014 \\ Copenhagen, Denmark. 18-21 September 2014
}

\section{Objectives}

To demonstrate that an appropriate pain control in patients with vascular dementia (VD) depends on good pain evaluation and may express an improvement in behavior and daily activities.

\section{Methods}

56 patients were diagnosed in the last two years with advanced vascular dementia according to clinical manifestations, vascular risk factors and neuroimaging which revealed brain atrophy and multiple focal lesions in the subcortical white matter. 21 of them suffered from neuropathic pain but were unable to reliably communicate their pain. So, we used Pain Assessment in Advanced Dementia Scale (PAINAD) whose total score ranges from 0 to 10 points, including mild pain (1-3), moderate pain (4-6) and severe pain (7-10). The lesions were $34 \%$ compressive-disc prolapse in the spine, producing sciatica or cervico-brachial nevralgia, $15 \%$. were infiltrative as paraneopastic polineuropathy and $51 \%$ due to damage to the nerve itself by an intrinsec process-diabetic, alcoholic neuropathy, postherpetic neuralgia. The pain responded well to antiseizures and antidepressant medication.

\section{Results}

From 21 patients treated with painkillers others than opioids, 15 revealed marked cognitive and behavior improvement concerning especially apathy, depression and incontinence of affect-involuntary laughing and crying.

\section{Conclusion}

The patients with white matter lesions, particularly those noncommunicative, but also demented patients who report less prevalent pain, must be considered at high

${ }^{1}$ Neurology, Clinical Hospital Pelican, Oradea, Romania

Full list of author information is available at the end of the article risk for undertreatment of pain. That's why, we have to use the screening instruments to check the existence of pain, first and then to check whether the pain is neuropathic.-Leeds Assessment for Neuropathic Symptoms and Signs (LANSS) and Pain DETECT.

No conflict of interest.

\section{Authors' details}

${ }^{1}$ Neurology, Clinical Hospital Pelican, Oradea, Romania. ${ }^{2}$ Student, University of Medicine and Pharmacy, Cluj Napoca, Romania.

Published: 18 September 2014

doi:10.1186/1129-2377-15-S1-C59

Cite this article as: Tertan and Tertan: EHMTI-0027. The neuropathic pain in vascular dementia. The Journal of Headache and Pain 201415 (Suppl 1):C59.

\section{SpringerOpen $^{\odot}$}

C 2014 Tertan and Tertan; licensee Springer. This is an Open Access article distributed under the terms of the Creative Commons Attribution License (http://creativecommons.org/licenses/by/2.0), which permits unrestricted use, distribution, and reproduction in any medium, provided the original work is properly cited.

Submit your manuscript to a SpringerOpen ${ }^{\circ}$ journal and benefit from:

- Convenient online submission

- Rigorous peer review

- Immediate publication on acceptance

- Open access: articles freely available online

- High visibility within the field

Retaining the copyright to your article

Submit your next manuscript at $>$ springeropen.com 